\title{
The genetic differentiation of a cricket (Velarifictorus micado) with two modes of life cycle in East Asia after the middle Pleistocene
}

\author{
baiqiu Wang ${ }^{1}$, Kai $\mathrm{Li}^{1}$, and Zhu-Qing $\mathrm{HE}^{1}$ \\ ${ }^{1}$ Affiliation not available
}

May 6, 2020

\begin{abstract}
Cricket Velarifictorus micado is widely distributed in East Asia and colonized North America since 1959. It has been reported that they had two modes of life cycle and distributed in southern and northern Asia respectively. Aimed to investigate the biogeographic boundary between the two groups and the causes of differentiation, mitochondrial fragments including COI and CytB were used for phylogenetic analysis, time estimation and demographic analysis. The results showed that, (i) Haplotype network indicated that V. micado has diversified to three lineages based on COI. Individuals with egg diapause lived in northern Asia, whereas those with egg and nymph diapause lived in southern Asia, and the populations colonized North America belongs to the egg diapause group from both North and South Asia. (ii) The molecular chronograms indicated that the first diversification between individuals in the northern and southern Asia occurred during 0.79 Ma BP in the Middle Pleistocene Transition. The second event occurred in southern individuals during $0.49 \mathrm{Ma}$ BP, when the glaciers developed in Yulong mountain (Yunnan province). (iii) V. micado has diversified to two main clades based on CytB. The individuals distributed in southern China have not been differentiated. Haplotype network indicated that the egg diapause lived in southern China most possibly originated from Yunnan, where lies at the foot of the Tibetan plateau. Our study suggested that the twice divergence of V. micado co-occurred with tendency of cooling climatic in Asia after the Mid-Pleistocene.
\end{abstract}

\section{Questions the manuscript attempts to address}

Cricket Velarifictorus micado was found that it had two modes of life cycle. However, there are still three questions unsolved.

1. Their distribution in most regions of East Asia

Method: Wide sampling

2. Gene markers that were diversified between two groups

Method: Amplify mitochondrial fragments

3. Divergence time and the possible reasons why they were differentiated.

Methods:

(i). The time estimation based on COI to reveal which important events result in the divergence of the $V$. micado. (ii). The evolutionary difference between two genes to speculate the origin of the ancient residents.

\section{Introduction}

The extant species in the planet have evolved for hundreds of millions of years. Evidence of climatic and environmental changes could be found through the adaptation of species and the historical development of the population within the species (Emerson et al ., 2001). Lucky individuals survived when the environment had changed dramatically. They migrated to the new habitat, and they settled, adapted and reproduced 
there. In the process of adaptation, new behavioral, physiological and genetic structure occurred (Avise et al ., 1998). Speciation duration is about 1-2 Myr, but morphological, physiological and behavioral changes may produce subspecies and species at almost any time (Hewitt et al. , 2000). The current distribution and the differentiation of species are compatible with the local geographical and climatic environment (Udvardy, 1981). Insects have the relatively rapid divergence rate (Orr et al ., 1998). Velarifictorus micado, selected in our study, is widely distributed in Asia, included China, Russia, Japan, Korea, Cambodia, Vietnam, Indonesia and nearby islands, covering the Palearctic and Oriental realm, and the distribution range of this cricket has gradually expanded since the introduction of V. micado to the United States in 1959 (Alexander and Walker, 1962; Bowles, 2018). Velarifictorus micado (Saussure, 1877) has been found to have two modes of life cycle. In a population that diapause as eggs, adults sing from August to October, and their eggs hatch after getting through the winter. In the other population that diapause as nymphs, adults sing in May-July, hatch quickly after mating and get through the winter as nymphs. Different adaptation types of $V$. micado lead to differentiation of reproductive modes and stimulate speciation among populations with different life cycle patterns (He and Takeda, 2013). Aimed to find out which gene markers can distinguish the two groups and the biogeographic boundary between them, figure out why $V$. micado differentiate into two modes of life cycle, mitochondrial fragments were extracted from the large sampling specimens and used in phylogenetic analysis, time estimation and demographic analysis.

\section{Materials and methods}

\subsection{Sample collection and genomic DNA extraction}

A total of 72 Velarifictorus micado populations contain 346 individuals were collected, 57 populations from China, one from Korea, eight from Japan, one from Vietnam, one from Cambodia and four from America (Fig. 1). All materials were presented in $100 \%$ ethanol and stored in a freezer at $-20^{\circ} \mathrm{C}$, genomic DNA was extracted from the leg of the cricket using AxyPrep ${ }^{\mathrm{TM}}$ Multisource Genomic DNA Miniprep kit.

\subsection{PCR amplification and sequencing}

Universal primers for cytochrome c oxidase unit 1 (COI), and cytochrome b (CytB) genes were designed in the present study (Table 1). The PCR procedure for the three genes included an initial denaturation at $94 \mathrm{deg} \mathrm{C}$ for $4 \mathrm{~min}$, followed by 35 cycles of $30 \mathrm{~s}$ at $94 \mathrm{degC}, 30 \mathrm{~s}$ at $45 \mathrm{degC}$ and $30 \mathrm{~s}$ at $72 \mathrm{degC}$, ending with a final extension at $72 \mathrm{degC}$ for $5 \mathrm{~min}$. Sequencing was performed on $3730 x l$ DNA Analyzer, sequencing was proofread and aligned in ATGC Ver 7.0.2 (Genetyx Corporation, Tokyo, Japan).

\subsection{Genetic analysis}

\subsubsection{Genetic polymorphism}

Base substitution saturation test was performed in DAMBE (Xia and Xie, 2001) to make sure ISS < ISS.cSym. Different haplotype, Haplotype diversity $(\mathrm{Hd})$ and nucleotide diversity $(\pi)$ were calculated in DNASP 5.10.01 (Librado and Rozas, 2009), A median joining (MJ) haplotype network was constructed in Popart (Leigh and Bryant, 2015), each population has its own color. Genetic differentiation among different populations and sets that defined groups was calculated in ARLEQUIN 3.5.2.2 (Excoffier and Lischer, 2010). Analyses of Pairwise $F_{S T}$ were performed in two ways. The first comprising data sets divided by the different modes of life cycle mainly and the second sets divided by the main zoogeographic regions (Zhang, 1983) comprising NEC (northeastern China), NC (northern China), SWC (southwestern China), CC (central China), SC (southern China), VK (Vietnam and Cambodia), KJ (Korea and Japan) and USA (The United States) data (Table 2).

\subsubsection{Historical demographic changes}

Haplotype diversity, nucleotide diversity and neutrality test were used to speculate historical demographic change. Neutrality tests were implemented in ARLEQUIN 3.5.2 (Excoffier and Lischer, 2010), including Tajima' D (Tajiama, 1989) and Fu' Fs (Fu, 1997).

\subsubsection{Divergence time estimation}


Estimating divergence times were based on mitochondrial markers of COI in BEAST 2.5.0 (Bouckaert et al ., 2014). A set of 15 specimens comprising 6 Velarifictorus specimens and 9 ancient haplotypes of $V$. micado was employed for the estimation of divergence time (Table 3). The substitution models were selected under JModeltest v.2 (Darriba et al ., 2012). The Bayesian information criterion (BIC) was preferentially used to compare substitution models, and HKY $+\mathrm{I}+\mathrm{G}$ model of sequence evolution was selected. An uncorrelated lognormal relaxed clock was applied with $1.7 \%$ per site per lineage per million years for COI (Pons and Vogler, 2005; Kiyoshi and Sota, 2006; Sharipo,et al ., 2006; Papadopoulou et al ., 2010; Allegrucciet al ., 2011; Kaya et al ., 2016). Divergence time was estimated using a Yule model. After running the chains for 500 million generations in BEAST, the stability on the log-likelihood curves and the split-frequencies were checked in Tracer v1.7.1. The parameter estimates with ESS $>200$ were accepted. Discarding the first $20 \%$ as burn-in and summarize trees in Tree Annotator. Trees were visualized with the FigTree v1.1.2 (These software are included in the BEAST package).

\section{Results}

\subsection{Genetic polymorphism and haplotype network}

COI gene $(658 \mathrm{bp})$ was successfully obtained from 346 individuals. The variable sites included 12 singleton variable sites and 33 parsimony information sites. 36 unique haplotypes were derived from 346 individuals. The distribution of different haplotypes based on COI was showed in Fig.2. The haplotype distributions were dividing three starry shapes in the network. According to the haplotype network, the geographical populations were further divided into 85 populations and this was done for further analysis of individuals from different lineages in the same collection site. 85 populations belonged to three groups, which included NE, SE and SN group. NE contained the individuals that produced with egg diapause and mainly lived in the northern regions. SE included the populations with egg diapause and mainly lived in the southern regions. SN group was consisted with individuals that produced with nymph diapause and mainly lived in the southern regions (Table 2). The location of three groups was showed in the Fig.1. There was no sharing haplotype among three groups. Hap24, Hap 2, Hap 4 and Hap 11 haplotypes were the most frequent haplotypes, characterizing $25.72 \%, 25.14 \%, 17.92 \%, 4.05 \%$ individuals, respectively. Hap 2 and Hap 11 were the ancestral haplotypes of NE group, and Hap11 was disjoint from Hap 2, which suggested was differentiated due to the long distance. Hap 4 and Hap 24 were the ancestral haplotypes of SE and SN groups, respectively. There were two lineages in populations of SDDY, but the haplotypes of the residents of SDDY belonged to the SE were the tips of Hap 2, thus the SE lineage may immigrate lately. In additional, the haplotypes from the United States were the tips of the gene tree, Hap 5 and Hap 8 were originated from the NE group. Populations of USAGA3 and USATN3 shared hap 5 with JPDB3, JPSH3 and JPSS3 in Japan. Hap 7 was from SE group, populations of USAMO1 and USAVA1 shared hap 7 with SDDY1, ZJTM1 and SHBS1 in China (Fig.2 and Table 2).

Pairwise $F_{S T}$ among $\mathrm{SE}, \mathrm{NE}$ and $\mathrm{SN}$ groups range from 0.87072 to 0.95084 ( $\mathrm{P}<0.001$ Table 4 ), which suggested that the three groups were differentiated significantly. Isolations between SE, SN and NE group were consistent with results of AMOVA. The partitioning of total genetic variation in three clades using AMOVA indicated $93.23 \%$ diversity among groups, $2.78 \%$ within populations, and $4.00 \%$ among populations within groups (Table 5), suggesting that $V$. micado has significant genetic differentiation at the different mode of life cycle and geographical separation of northern and southern regions. According to the zoogeographic regions, 85 populations were divided into 8 regions, including NEC, NC, SWC, CC, VK, KJ and USA. The partitioning of total genetic variation in nine clades using AMOVA indicated $24.94 \%$ diversity among groups, $69.56 \%$ among populations within groups, and $5.49 \%$ within populations (Table 6 ). The results were consistent with the network based on COI, which meant the different modes of life cycle accounted for the most of genetic variation.

Based on the CytB gene, 579 bp fragments were successfully obtained from 162 individuals. The variable sites included 18 singleton variable sites and 31 parsimony information sites. 36 unique haplotypes were derived from 162 individuals. The distribution of different haplotypes was showed in Fig.3. All individuals were divided into two groups significantly. Hap 12 and Hap 13 were the ancestral haplotypes of northern 
China (NC), and Hap 4 was the ancient haplotypes of southern China (SC). Coincidentally, all the individuals in the NC group were the members of the NE group defined by the COI, and others were in the SE and SN group. There were two lineages in SDDY and SHBS, which mainly including Hap1, Hap15 and Hap12. While Hap1 and Hap 15 were the tips of Hap 4, thus the NE lineage may be the native in SDDY and SHBS (Fig.3). This result was consisted with the assumption based on COI.

The partitioning of total genetic variation in different regions indicated $41.11 \%$ among populations within groups, $30.23 \%$ diversity among groups, and $28.66 \%$ within populations (Table 7 ). While the AMOVA result showed that the source of variation among groups categorized by three clades based on COI accounts $84.78 \%$ (Table 8).

\subsection{Historical demographic changes}

Based on COI, the negative of values of Tajima' D suggested a relative constant population size. In SHBS3, SDDY3 and SDTA3, the current population size is stable. The NE lineage may be the native in SDDY and SHBS, which is consistent to the results of haplotype network (Table 2). Based on CytB, the negative and significant values of Tajima' D indicated past population expansion in populations of GZXY (Guizhou province). Additionally, Hap 4 was the ancient haplotypes of populations of egg and nymph diapause. Individuals produced with nymph diapause in Zhejiang, Hainan and Guangxi (ZJTT, HNBS, HNJFL, HNWZ, HNCJ, HNXA, GXPM, GXSL and GXJX), whereas those were with egg and nymph diapause in Yunnan and Guizhou (YNKM and GZXY), which suggested the ancient haplotypes of SE group distributed there (Fig.3), and the positive Tajima' D value based on COI and CytB suggested there may be a colonization of SE group in Guizhou (Table 2 and 9). Thus, it is possibility that SE group was originated from Yunnan and colonize to the other regions.

\subsection{Divergence time estimation}

The chronogram reconstructed with BEAST was based on COI (Fig. 4). The most recent common ancestor for all V. micado was dated at approximately $0.79 \mathrm{Myr}$ (95\% HPD: 0.46-1.13Myr). The diversification time between SN and SE clades was 0.50 Myr (95\% HPD: 0.25-0.71Myr).

\section{Discussion}

\subsection{Life cycle and distribution}

$V$. micado has two ways to get through the winter, one group prefer to nymph diapause, the other group choose to egg diapause (He and Takeda, 2013). Adults of egg diapause population were found from July to October (Shandong, Heilongjiang, Henan, Guizhou and Yunnan), and nymphs were from July to August (Shandong and Yunnan). The individuals with nymph diapause, as we found, were adults in March (Hainan), April (Guangxi), June (Hubei and Zhejiang) and July (Guizhou). The nymph were found in the spring or the later autumn, such as March (Hainan), April (Guangxi), August (Guizhou), September and October (Zhejiang).

Our results indicated that V. micado was transferred to America, which is consistent with this result (Bowles, 2018). V. micadowas first found in the North America since 1959 (Alexander and Walker 1962), then they were widely distributed around eastern and southeastern America (Walker 1977; Peck et al . 1992). The recent research indicated the cricket had dispersed both northwards and westwards (Bowles, 2018). Our results revealed they might be immigrated from China and Japan, and belongs to the egg diapause populations. Their distribution range in the United States might continue to expanding due to their adaptation to dry and cold areas, for example, they were widely distributed in the northeastern China. Limited to sampling size, it is unknown if there are nymph populations in North America. The mitochondrial fragment COI could be easily used to check the origin of $V$. micado for prevention of invasion. The similar latitude and climate make the species orginated from North America easy to settle down to China, such as Corythucha ciliata, Homalodisca coagulata and Anopheles quadrimaculatus (Li et al ., 2007; Wang et al ., 2008; Zhang et al ., 2008) and vice versa. Similarly, V. micado was easy to adapt to the environment of North America. Although it has not been found that this cricket has destructive damage to human and nature, the impact 
to system of the new colony is unknown. Besides, although sampling size was small, individuals in Vietnam and Cambodia might be native due to the ancient haplotype.

The wide sampling in Asia enabled us to find the distribution of two groups and compare differences between them. The egg diapause population lives in both the north and south of the Yangtze River. Based the COI, the NE group contained the populations lived in north of the Yangtze River regions as well as those in Shanghai and Zhejiang. These populations have the ancient haplotypes and have not migrated previously and recently through the values of Tajima' D. The SE group is distributed in the south of the Yangtze River regions as well as those in Hubei, Jiangsu and Shandong. The haplotypes were the tips of gene tree in Shandong and Jiangsu, maybe the SE group was introduced. However, there was ancient haplotype in Hubei. Limited to the sample size, it is uncertain whether the three populations migrated before. The SN group included the populations lived in the south of Yangtze River and HBWH (Hubei). The two individuals are the ancient haplotype in Hubei, but it is also uncertain whether there was a migration before. Based on CytB, all individuals were divided into two groups, NC (northern China) group contains the populations lived in the north of the Yangtze River regions as well as those in Shanghai and Zhejiang, in which there is ancient haplotype. SC (southern China) group contains the populations lived in the south of the Yangtze River regions as well as those in Hubei, Anhui, Shandong, in which there are both tips of gene tree, and these individuals may immigrate into the north of the Yangtze River artificially or naturally. This phenomenon with two life histories bounded by the Yangtze River could be seen between Teleogryllus emma and $T$. occipitalis (He et al ., 2017).

According to the distribution of species, there is a broad faunal transition zone in the Quaternary between the Palearctic and Oriental realm in China (Zhang, 2002) and no strict biogeographic division (Norton et al ., 2011). However, a map of zoogeographic regions generated by phylogenetic relationships of species shows that there are three realms containing Palearctic realm, Sino-Japanese realm and Oriental realm (Holt et al., 2013). However, our results were basically consistent with an earlier suggestion of Wallace (Wallace, 1876). The Yangtze River is the biogeographic boundary between the Oriental and Palearctic. Although it is not strictly defined by the Yangtze River, Shandong, Jiangsu, Shanghai and Zhejiang regions are the intersection of groups. Those are the broad transition zone for V. micado. When the cool climate shift occurred in the mid-Pleistocene, the northern individuals immigrate southwards. When the glaciation in the southwestern mountain, the native residents immigrate eastwards the refuge, but some remained and scattered. The analysis is as following.

\subsection{Divergence time and induced causes}

Phylogenetic analysis and haplotype network have well supports that $V$. micado has diversified to two main lineages (NE and $\mathrm{SE}+\mathrm{SN}$ ) and two modes of life cycle (egg diapause and nymph diapause), and they are evolved independently. There are three main questions. The first question concerns the divergence of $V$. micado. Which important events triggered them dividing to two main clades (NE and SN+SE)? The second question is which climate shifts led them had developed two modes of life cycle? The third question is about the sympatric co-existence of two modes of life cycle of $V$. micado, what made them differentiate?

The time estimation analysis is the most reliable criterion to confirm which important events or climate shifts result in the divergence of the $V$. micado. Although the rate of CytB is bigger than COI (Brower and DeSalle, 1998; Gray et al ., 2006), the individuals lived in south Asia have not diversified based on CytB. Thus, the divergence in COI occurred early than CytB after the climate shifts, and COI was selected to estimate the time of diversification.

Climate changes during the Quaternary have great effects on species, for example, climate oscillation occurred during Pleistocene has affected the distribution of species Gymnocarpos przewalskii in Northwestern China (Jia and Zhang, 2019), the genetic divergence in species as Petrogale penicillata in southeast Australia appear to date to the mid-Pleistocene (Hazlitt et al ., 2014) and even contributed to speciation of arcticalpine Campanula occurred in mid-Pleistocene in western North America (DeChaine et al ., 2014). According to the researches about Quaternary glaciations in Asia, the climatic transformation of Asia occurred in 0.8 
Ma BP was closely related to Mid-Pleistocene Transition (MPT), which was called due to glacial-interglacial cycles from a 41 ka to 100ka dominant frequency (Pisias et al ., 1981; Ruddiman et al ., 1989; Raymoet al ., 1998), and the Kunhuang (Kunlun Huanghe) movement of 0.9 Ma BP, (Li et al ., 2001; Li et al ., 2004). Since 800 ka BP, there were 8 complete glacial-interglacial cycles with a 100-ka dominant frequency (Shackleton and Opdyke, 1977). During these global glacials after the Kunhuang movement, glaciers developed gradually in the various part of the Qinghai-Tibet plateau (Wu et al ., 1999; Yao et al ., 2000; Zheng, 2000; Zhou et al ., 2002). Mountains lower than $2000 \mathrm{~m}$ in the East China were no glaciers during the middle Pleistocene (Shi et al ., 1987). The deposit sediment and the current distribution of the extant land species were related to the geographical and climatic shifts since the Quaternary. The most recent Vermiculated Red Soil (VSR) in southern China, an indication of extremely warm and humid conditions, was formed about 0.85 Ma BP due to the strengthen summer monsoon in the middle Pleistocene (Yang et al ., 1996; Qiao et al ., 2003) and the summer monsoon also strengthened in northern China (Guo et al ., 1998). However, subtropical zone reached at $42^{\circ} \mathrm{N}$ before the middle Pleistocene, and retreated southwards after the mid-Pleistocene (Liu and Ding, 1983). Many species immigrated southwards, including boreal, thermophilic and humid-preferring fauna. The species adapted to the new environment, and some remained and scattered in the locality during the Quaternary glaciation (Zhang, 2004). The current distribution of these species revealed the overall trend after the climate oscillations. The divergence time between northern and southern individuals was dated to $0.79 \mathrm{Ma}$, which was basically consistent with this time, thus, it is possible that the life history of the individuals lived in northern China changed under the tendency of change towards cooling climate. During the MPT, mid-Pleistocene Homo (MPH) (Bae, 2010; Wu and Poirier, 1995) in East China adapted to the diverse and various climate, distributing from the temperate to subtropical zone (Guo et al ., 2018; Kong et al ., 2019). The climate shifts in MPT induced the diversification and distribution of species, and we observed that this cricket is common around the habitats of human, but not in the wild. It is possible that human behavior influenced the distribution of the cricket to some extent after the mid-Pleistocene.

The earliest Yunshanping moraine in Yulong mountain (Yunnan province) was dated to $592.6 \pm 118.5 \mathrm{ka}$ BP (Zheng, 2000). Yao conducted dating studies on the red moraine in the same mountain, the ages of several samples range from 500 to $600 \mathrm{ka} \mathrm{BP}$ (Yao et al ., 2000). The second differentiation occurred during 0.50 Ma between southern individuals with egg and nymph diapause populations, and our results showed the egg diapause population might originated from Yunnan. Thus, the individuals with nymph diapause changed to get through the winter with egg due to the dry and cool climate.

The behavioral and genetic changes in the southern residents correspond to the environmental transitions. The genetic diversity indices and the phylogenetic analysis are the reliable evidence to support that the differentiation among sympatric co-existence of $V$. micado with two modes of life cycle has occurred for a long time. The divergence between them is maintained in the absence of obvious environmental difference and barriers to gene flow, such as the same photoperiod, temperature, humidity and habitats, while the genomic underpinning of ecological speciation often appear to have been found to be the result of a long period of allopatry (Bernatchez and Dodson, 1990; Federet al., 2003; Gray et al ., 2006; Kuehne et al . 2007; Foote and Morin 2015; Lucek et al ., 2018). The egg diapause population might origin from Yunnan colonized the new habitat. The individuals lived in the same locality may choose differently suitable habitats to their own life cycle.

It should be noted that there are still parts to be improved in our research. First, the range of the sampling time in the tropical region of China should be increased to further figure out if there was the egg diapause population. Second, are genes (COI and $\mathrm{CytB}$ ) and behavior differentiation (different modes of life cycle) just two independent responses to the dramatic environment? Has the efficiency of the function of COI changed in individuals with two modes of life cycle? Or maybe it's just due to the founder effect. As this research shows, a large of proportion of genetic variation is originated from the founder effect rather than natural selection in human populations (Ramachandranet al ., 2005).

\section{Acknowledgements}

The authors thank Li Jin, Gong Pu, Jin Cheng-Yan, Wang Jie-Jing, Takeda Makio, Hu Jia-Yao, Tang Liang, 
Lin Yi-Xiang, Zhang Tao, Chang Wen-Hao, Luo Yi, Cheng Mu-Hua, Li Mao-Wei, Wu Shi-Hai, Zhu Xiao-Yu, Jiang Ye, Shen Yi-Kan and everyone in our laboratory provide the specimens of V.micado. Funding for this work was provided by the National Natural Science Foundation of China (No. 31801997), the Natural Science Foundation of Shanghai (19ZR1416100)

\section{Conflict of interest}

The authors declare no conflict of interest.

\section{Authors' contribution}

B. W., K. L., and Z. H. designed the research. B. W. and Z. H. performed the experiments. B. W. analyzed the data and wrote the paper. K. L. reviewed the paper.

\section{Data availability statement}

DNA sequences are depositing to Genbank.

\section{References}

Alexander R.D., \& Walker T. J. (1962). Two introduced field crickets new to eastern united states (Orthoptera: Gryllidae). Annals of the Entomological Society of America (1), 1. https://doi.org/10.1093/aesa/55.1.90

Allegrucci, G., Trucchi, E., \& Sbordoni, V. (2011). Tempo and mode of species diversification in Dolichopoda cave crickets (Orthoptera, Rhaphidophoridae). Molecular Phylogenetics and Evolution, 60(1), 108-121. https ://doi.org/108-121. 10.1016/j.ympev.2011.04.002

Avise, J. C., Walker, D., \& Johns, G. C. (1998). Speciation durations and Pleistocene effects on vertebrate phylogeography. Proceedings of the Royal Society of London. Series B: Biological Sciences , 265(1407), 17071712. https://doi.org/10.1098/rspb.1998.0492

Bae, C. J. (2010). The late Middle Pleistocene hominin fossil record of eastern Asia: Synthesis and review. American Journal of Physical Anthropology , 143, 75-93. https://doi.org/10.1002/ajpa.21442

Bernatchez, L., \& Dodson, J. J. (1990). Allopatric origin of sympatric populations of lake whitefish (Coregonus Clupeaformis) as revealed by mitochondrial-DNA restriction analysis. Evolution , 44(5), 1263-1271. https://doi.org/10.2307/2409287

Bouckaert, R., Heled, J., Kuhnert, D., Vaughan, T., Wu, C. H., Xie, D., .. \& Drummond, A. J. (2014). BEAST 2: a software platform for Bayesian evolutionary analysis. PLoS computational biology , 10(4). https://doi.org/10.1371/journal.pcbi.1003537

Bowles, D. E. (2018). Introduced Japanese burrowing cricket (Orthoptera: Gryllidae: Velarifictorus (Velarifictorus) micado) range continues to expand in North America. Journal of Orthoptera Research, 27(2), 177-181. https://doi.org/10.3897/jor.27.29067

Brower, A. V. Z., \& DeSalle, R. (1998). Patterns of mitochondrial versus nuclear DNA sequence divergence among nymphalid butterflies: the utility of wingless as a source of characters for phylogenetic inference. Insect Molecular Biology , 7(1), 73-82. https://doi.org/10.1046/j.1365-2583.1998.71052.x

Chen, G. Y., Shen, C. Z., Liu, Y. F., Liao, W., \& He, Z. Q. (2018). A phylogenetic study of Chinese Velarifictorus randell, 1964 based on COI gene with describing one new species (Orthoptera: Gryllidae: Gryllinae). Zootaxa, 4531(4). https://doi.org/10.11646/zootaxa.4531.4.2

Darriba, D., Taboada, G. L., Doallo, R., \& Posada, D. (2012). jModelTest 2: more models, new heuristics and parallel computing. Nature methods , 9(8), 772-772. https://doi.org/10.1038/nmeth.2109

DeChaine, E. G., Wendling, B. M., \& Forester, B. R. (2014). Integrating environmental, molecular, and morphological data to unravel an ice-age radiation of arctic-alpine Campanula in western North America.Ecology and Evolution , 4(20), 3940-3959. https://doi.org/10.1002/ece3.1168 
Emerson, B. C., Paradis, E., \& Thebaud, C. (2001). Revealing the demographic histories of species using DNA sequences. Trends in Ecology $\&$ Evolution , 16(12), 707-716. https://doi.org/10.1016/S0169$5347(01) 02305-9$

Excoffier, L., \& Lischer, H. E. (2010). Arlequin suite ver 3.5: a new series of programs to perform population genetics analyses under Linux and Windows. Molecular ecology resources , 10(3), 564-567. https://doi.org/10.1111/j.1755-0998.2010.02847.x

Feder, J. L., Berlocher, S. H., Roethele, J. B., Dambroski, H., Smith, J. J., Perry, W. L., .. \& Aluja, M. (2003). Allopatric genetic origins for sympatric host-plant shifts and race formation in Rhagoletis. Proceedings of the National Academy of Sciences , 100(18), 10314-10319. https://doi.org/ 10.1073/pnas.1730757100

Foote, A. D., \& Morin, P. A. (2015). Sympatric speciation in killer whales?. Heredity, 114(6), 537-538. https://doi.org/10.1038/hdy.2014.120

Fu YX (1997) Statistical tests of neutrality of mutations against population growth, hitchhiking and background selection.Genetics , 147, 915-925.

Gray, D. A., Barnfield, P., Seifried, M., \& Richards, M. H. (2006). Molecular divergence between Gryllus rubens and Gryllus texensis, sister species of field crickets (Orthoptera: Gryllidae). The Canadian Entomologist , 138(3), 305-313. https://doi.org/ 10.4039/n05-037

Guo, Y., Sun, C., Luo, L., Yang, L., Han, F., Tu, H., Shen, G. (2019). 26 Al/ 10 Be Burial Dating of the Middle Pleistocene Yiyuan Hominin Fossil Site, Shandong Province, Northern China. Scientific Reports, 9(1), 6961. https://doi.org/10.1038/s41598-019-43401-5

Guo, Z., Liu, T., Fedoroff, N., Wei, L., Ding, Z., Wu, N., \& An, Z. (1998). Climate extremes in Loess of China coupled with the strength of deep-water formation in the North Atlantic. Grid and Pervasive Computing , 18(3), 113-128. https://doi.org/ 10.1016/s0921-8181(98)00010-1

Hazlitt, S. L., Goldizen, A. W., Nicholls, J. A., \& Eldridge, M. D. B. (2014). Three divergent lineages within an Australian mar-supial (Petrogale penicillata) suggest multiple major refugia for mesic taxa in southeast Australia. Ecology and Evolution 4(7): 1102-1116. http://dx.doi.org/10.1002/ece3.1009

He, Z. Q., \& Takeda, M. (2013). Discrete modes of life cycle in Velarifictorus micado Species Complex (Orthoptera: Gryllidae).ISRN Entomology, 2013. http://dx.doi.org/10.1155/2013/851581.

He, Z. Q., W, X. Y., L, Y. Q., \&Li, K. (2017). Seasonal and geographical adaption of two field crickets in China (Orthoptera: Grylloidea: Gryllidae: Gryllinae: Teleogryllus). Zootaxa , 4338(2), 374-384. https://doi.org/10.11646/zootaxa.4338.2.11.

Hewitt, G. (2000). The genetic legacy of the Quaternary ice ages.Nature , 405(6789), 907. https://doi.org/ $10.1038 / 35016000$

Holt, B. G., Lessard, J. P., Borregaard, M. K., Fritz, S. A., Araujo, M. B., Dimitrov, D., ... NoguesBravo, D. (2013). An update of Wallace's zoogeographic regions of the world. Science, 339(6115), 74-78. https://doi.org/10.1126/science.1228282

Jia, S. W., \& Zhang, M. L. (2019). Pleistocene climate change and phylogeographic structure of the Gymnocarpos przewalskii (Caryophyllaceae) in the northwest China: Evidence from plastid DNA, ITS sequences, and Microsatellite. Ecology and Evolution, 9(9): 5219-5235. https://doi.org/10.1002/ece3.5113

Kaya S, \& Ciplak B. (2016). Budding speciation via peripheral isolation: the Psorodonotus venosus (Orthoptera, Tettigoniidae) species group example. Zoologica Scripta 45: 521-537. https://doi.org/10.1111/zsc.12174

Kiyoshi T., \& Sota T., (2006). Differentiation of the dragonfly genusDavidius (Odonata: Gomphidae) in Japan inferred from mitochondrial and nuclear gene genealogies. Zoological. Science . 23, 1-8. https://doi.org/10.2108/zsj.23.1 
Kong, Y., Deng, C., Liu, W., Wu, X., Pei, S., Sun, L., ... Zhu, R. (2018). Magnetostratigraphic dating of the hominin occupation of Bailong Cave, central China. Scientific Reports , 8(1), 1-12. https://doi.org/10.1038/s41598-018-28065-x

Kuehne, H. A., Murphy, H. A., Francis, C. A., \& Sniegowski, P. D. (2007). Allopatric divergence, secondary contact, and genetic isolation in wild yeast populations. Current Biology , 17(5), 407-411. https://doi.org/10.1016/j.cub.2006.12.047

Leigh, J. W., \& Bryant, D. (2015). Popart: full-feature software for haplotype network construction. Methods in Ecology and Evolution , 6(9), 1110-1116. https://doi.org/10.1111/2041-210X.12410

Li, C. R., Xia, W. S., \& Wang, F. L. (2007). First records of Corythucha Ciliata in China (Hemiptera, Tingidae). Acta Zootaxonomica Sinica (in Chinese), 32(4), 944-946. https://doi.org/10.3969/j.issn.10000739.2007.04.038

Li, J. J. , Shu, Q. , Zhou, S. Z., Zhao, Z. J. , \& Zhang, J. M. (2004). Review and prospects of quaternary glaciation research in China. Journal of Glaciology and Geocryology .

Li, J. J., Fang, X. M, Pan, B. T., Zhao, Z. J., Song, Y. G. (2001) Late Cenozoic intensive uplift of QinghaiXizang Plateau and its impacts on environments in surrounding area. Quarternary. Sciences. 21: 381-391.

Librado, P., \& Rozas, J. (2009). DnaSP v5: a software for comprehensive analysis of DNA polymorphism data. Bioinformatics , 25(11), 1451-1452. https://doi.org/ 10.1093/bioinformatics/btp187

Liu, T. S. , \& Ding M. L. (1983).The characteristics and evolution of the Palaeoenvironment of China since Late Tertiary. Earth Science(in Chinese) (04), 21-34..

Lucek, K., Keller, I., Nolte, A. W., \& Seehausen, O. (2018). Distinct colonization waves underlie the diversification of the freshwater sculpin (Cottus gobio ) in the Central European Alpine region. Journal of evolutionary biology , 31(9), 1254-1267.

Norton, C. J., Jin, C., Wang, Y., \& Zhang, Y. (2011). Rethinking the Palearctic-Oriental Biogeographic Boundary in Quaternary China, Asian paleoanthropology. 81-100.

Orr, M. R., \& Smith, T. B. (1998). Ecology and speciation. Trends in Ecology \& Evolution, 13(12), 502-506. https://doi.org/10.1016/S0169-5347(98)01511-0

Papadopolou, A., I. Anastasiou \& A. P. Vogler. 2010. Revisiting the insect mitochondrial molecular clock: the mid-Aegean Trench calibration.Molecular Biology and Evolution . 27(7):1659-1672. https://doi.org/10.1093/molbev/msq051

Peck, S. B., Walker, T. J. \& Capinera, J. L. (1992). Distributional review of the Orthoptera of Florida. Florida Entomologist , 75(3), 329-342. https://doi.org/10.2307/3495854

Pisias, N. G. \& Moore, T. C. (1981). The evolution of the Pleistocene climate: a time series approach. Earth and Planetary Science Letters , 52(2), 450-458. https://doi.org/10.1016/0012-821x(81)90197-7

Pons, J., \& Vogler, A. P. (2005). Complex Pattern of Coalescence and Fast Evolution of a Mitochondrial rRNA Pseudogene in a Recent Radiation of Tiger Beetles. Molecular Biology and Evolution, 22(4), 9911000. https://doi.org/10.1093/molbev/msi085 Qiao, Y., Guo, Z., Hao, Q., Wu, W., Jiang, W., Yuan, B., ... Zhao, H. (2003). Loess-soil sequences in southern Anhui Province: Magnetostratigraphy and paleoclimatic significance. Chinese Science Bulletin, 48(19), 2088-2093. https://doi.org/10.1360/03wd0183

Raymo, M. E., Oppo, D. W., \& Curry, W. (1998). The mid-Pleistocene climate transition: a deep sea carbon isotopic perspective. Oceanographic Literature Review , 4(45), 650. https://doi.org/10.1029/97pa01019

Ruddiman, W. F., Raymo, M. E., Martinson, D. G., Clement, B. M., \& Backman, J. (1989). Pleistocene evolution: Northern hemisphere ice sheets and North Atlantic Ocean.Paleoceanography ,4(4), 353-412. https://doi.org/10.1029/PA004i004p00353 
Saussure, H. D. (1877). Melanges Orthopterologiques, Vme fasc. Gryllides. Memoires de la Societe Physique d'Histoire Naturelle de Geneve, 25, 1-352.

Shackleton, N. J., \& Opdyke, N. D. (1977). Oxygen isotope and palaeomagnetic evidence for early Northern Hemisphere glaciation. Nature , 270(5634), 216-219. https://doi.org/10.1038/270216a0

Shapiro, L. H., Strazanac, J. S., \& Roderick, G. K. (2006). Molecular phylogeny of Banza (Orthoptera: Tettigoniidae), the endemic katydids of the Hawaiian Archipelago. Molecular Phylogenetics and Evolution, 41(1), 53-63. https://doi.org/10.1016/j.ympev.2006.04.006

Shi Y. F., Cui Z. J., \& Li J. J. (1987). Reassessment of Quaternary glaciation problems in East China .Earth Sciences 2:45-54. Simmons, R. B., \& Weller, S. J. (2001). Utility and evolution of cytochrome b in insects. Molecular Phylogenetics and Evolution, 20(2), 196-210. https://doi.org/10.1006/mpev.2001.0958 Simon, C., Frati, F., Beckenbach, A., Crespi, B., Liu, H., \& Flook, P. (1994). Evolution, Weighting, and Phylogenetic Utility of Mitochondrial Gene Sequences and a Compilation of Conserved Polymerase Chain Reaction Primers. Annals of The Entomological Society of America, 87(6), 651-701. https://doi.org/10.1093/aesa/87.6.651

Tajima, F. (1989). Statistical method for testing the neutral mutation hypothesis by DNA polymorphism. Genetics , 123(3), 585-595.

Udvardy, F. (1981). Riddle of dispersal: dispersal theories and how they affect vicariance biogeography. Proceedings. vicariance Biogeography .

Walker, T. J. (1977) Japanese burrowing cricket widely established in southeastern United States. Florida Entomologist , 60: 308-309. https://doi.org/10.2307/3493933

Wallace, A. R. (1876). The geographical distribution of animals. Cambridge University. Press .

Wang, F. L., Li, C. R., Liu, W. X., \& Wan, F. H. (2008). Advances in research on biological characteristics and control techniques of the new invasive species Corythucha Ciliata. Scientia Silvae Sinicae (in Chinese), 44(6), 140-145. https://doi.org/CNKI:SUN:LYKE.0.2008-06-025

Wu Y. Q., Cui Z. J., Liu G. N. \& Ge D. K. (1999). Glaciation Sequences in the Kunlunshan Pass Area. Journal of Glaciology and Geocryology . 21(1), 71-76.

Wu, H. C., \& Poirier, F. E. (1995). Human evolution in China : a metric description of the fossils and a review of the sites.

Oxford University Press.

Xia, X., \& Xie, Z. (2001). DAMBE: software package for data analysis in molecular biology and evolution. Journal of heredity, 92(4), 371-373.

Yang, H., Zhao, Q. G., Li, X. P. \&Xia, Y. F. (1996). ESR chronological study on eolian deposition-red earth sequence in Xuancheng section in Anhui Province. Acta Pedologica Sinica (in Chinese), 33(3): 293-300..

Yao X. f., Guo Z.T., Zhao X.T., \& Wei L. Y. (2000). The discovery of palae-red earth at the east piedmont of Yulong Shan and its indicative significance to the uplift of Qinghai-Tibetan Plateau. Chinese Science Bulletin (in Chinese), 45(15):1 671-1 676..

Zhang, R. Z. (1987). Zoogeographical region (2). Zoogeographical region in China. Biological Bulletin (in Chinese) (3), 3-5.

Zhang, R. Z. (2002). Geological events and mammalian distribution in China. Acta Zoologica Sinica , 48(2), 141-153.

Zhang, R. Z. (2004). Relict distribution of land vertebrates and quaternary glaciation in China. Acta Zoologica Sinica , 50(5), 841-851. https://doi.org/10.3969/j.issn.1674-5507.2004.05.022 
Zhang, R. Z., Zhang, Y. P., \& Jiang, Y. X. (2008). The threat to China from the major invasion pests in the world. Science in China (in Chinese), 38(12): 1095-1102. https://doi.org/10.1360/zc2008-38-12-1095

Zheng Benxing. (2000). Quaternary Glaciations and their evolution patterns in Yulong Shan. Journal of Glaciology and Geocryology, 22(1):53-61.

Zhou, S., Li, J., \& Zhang, S. (2002). Quaternary glaciation of the Bailang River Valley, Qilian Shan. Quaternary International , 35643, 103-110.

Table 1 Primer sequences used in this study.

\begin{tabular}{llll}
\hline Gene region & Primer name & Sequence $(5,-3)$, & \\
\hline COI & LCO & GGTCAACAAATCATAAAGATATTGG & Simon et al., 1994 \\
& HCO & TAAACTTTCAGGGTGACCAAAAAATCA & \\
CytB & REVCB2H & TGAGGACAAATATCATTTTGAGGW & Simmons et al., 2001 \\
& REVCBJ & ACTGGTCGAGCTCCAATCATGT & \\
\hline
\end{tabular}

Table 2 Geographic information, nucleotide polymorphism and neutrality tests of 85 populations. S, number of segregating sites; Hap, haplotype distribution; Hd, haplotype diversity; $\pi$, nucleotide diversity; The number after the population name represents the groups divided by genetic marker COI which it belongs to, 1 represents it belongs to NE group. 2 and 3 represents SN group and SE group, respectively. The bold black font represents the groups divided by zoogeographic regions.

\begin{tabular}{|c|c|c|c|c|c|c|c|}
\hline population & Lat. & Long. & Sampling time & phase & Sample size & $\mathrm{S}$ & Hap \\
\hline \multicolumn{8}{|l|}{ NEC } \\
\hline HLJ3 & $\mathrm{N} 46^{\circ} 02^{\prime} 57.67^{\prime \prime}$ & $\mathrm{E} 125^{\circ} 57^{\prime} 22.18^{\prime \prime}$ & 2019.08.18 & adult & 11 & 0 & h 11 \\
\hline LN3 & $\mathrm{N} 41^{\circ} 40^{\prime} 30.64^{\prime \prime}$ & $\mathrm{E} 123^{\circ} 27^{\prime} 30.98^{\prime \prime}$ & & & 1 & 0 & h11 \\
\hline JL3 & $\mathrm{N} 43^{\circ} 50^{\prime} 45.16^{\prime \prime}$ & E126 $33^{\prime} 35.93 "$ & & & 2 & 1 & h11, h 34 \\
\hline \multicolumn{8}{|l|}{ NC } \\
\hline BJ3 & N39 $54^{\prime} 11.46^{\prime \prime}$ & $\mathrm{E} 116^{\circ} 24^{\prime} 2.71^{\prime \prime}$ & & & 1 & 0 & h 2 \\
\hline HNJY3 & $\mathrm{N} 35^{\circ} 04^{\prime} 42.16^{\prime \prime}$ & $\mathrm{E} 112^{\circ} 42^{\prime} 26.30^{\prime \prime}$ & 2019.08 .15 & adult & 22 & 1 & h $2(21)$, h 28 \\
\hline HNPY3 & N35 $51^{\prime} 7.02^{\prime \prime}$ & E115⒉ $29^{\prime} 53.63^{\prime \prime}$ & 2019.10 .03 & adult & 1 & 0 & h 2 \\
\hline SXXA3 & $\mathrm{N} 34^{\circ} 20^{\prime} 33.29^{\prime \prime}$ & E108 $56^{\circ} 7.28^{\prime \prime}$ & & & 1 & 0 & h 36 \\
\hline SXNS3 & $\mathrm{N} 33^{\circ} 18^{\prime} 44.97^{\prime \prime}$ & E10818'33.70" & & & 1 & 0 & h 2 \\
\hline SCCD3 & N30 $39^{\prime} 8.18^{\prime \prime}$ & $\mathrm{E} 104^{\circ} 04^{\prime} 20.98^{\prime \prime}$ & & & 1 & 0 & h 2 \\
\hline SDDY1 & N37 $26^{\prime} 53.41^{\prime \prime}$ & $\mathrm{E} 118^{\circ} 34^{\prime} 35.12^{\prime \prime}$ & 2019.07 .25 & adult & 2 & 3 & h 1, h 7 \\
\hline SDDY3 & $\mathrm{N} 37^{\circ} 26^{\prime} 53.41^{\prime \prime}$ & $\mathrm{E} 118^{\circ} 34^{\prime} 35.12^{\prime \prime}$ & 2019.08 .14 & adult & 12 & 1 & h $2(11)$, h $23(1)$ \\
\hline SDTA3 & N36ㅇ' $3.16^{\prime \prime}$ & $\mathrm{E} 116^{\circ} 43^{\prime} 12.42^{\prime \prime}$ & 2019.08 .15 & adult & 16 & 0 & h 2 \\
\hline \multicolumn{8}{|l|}{$\mathrm{CC}$} \\
\hline HBXY1 & N320'39.61" & $\mathrm{E} 112^{\circ} 06^{\prime} 57.21^{\prime \prime}$ & 2019.09 .25 & adult & 4 & 0 & h 24 \\
\hline HBWH2 & $\mathrm{N} 32^{\circ} 0^{\prime} 39.61^{\prime \prime}$ & $\mathrm{E} 112^{\circ} 06^{\prime} 57.21^{\prime \prime}$ & 2019.08 .04 & adult & 2 & 0 & h 4 \\
\hline ANNF3 & $\mathrm{N} 31^{\circ} 49^{\prime} 20.30^{\prime \prime}$ & $\mathrm{E} 117^{\circ} 13^{\prime} 17.39^{\prime \prime}$ & 2019.10.01 & & 1 & 0 & h 2 \\
\hline JSNJ3 & N32 $03^{\prime} 57.43^{\prime \prime}$ & $\mathrm{E} 118^{\circ} 46^{\prime} 56.02^{\prime \prime}$ & & & 2 & 0 & h 2 \\
\hline JSYZ1 & $\mathrm{N} 32^{\circ} 23^{\prime} 46.68^{\prime \prime}$ & E119 $24^{\circ} 27.01^{\prime \prime}$ & & & 1 & 0 & h 1 \\
\hline JSZJ1 & $\mathrm{N} 32^{\circ} 11^{\prime} 25.78^{\prime \prime}$ & $\mathrm{E} 119^{\circ} 25^{\prime} 6.73^{\prime \prime}$ & & & 1 & 0 & h 1 \\
\hline GZXY1 & $\mathrm{N} 25^{\circ} 05^{\prime} 41.85^{\prime \prime}$ & E104 $53^{\circ} 36.79^{\prime \prime}$ & 2019.07 .25 & adult & 6 & 1 & h $24(3)$, h $25(3)$ \\
\hline GZXY2 & $\mathrm{N} 25^{\circ} 05^{\prime} 41.85^{\prime \prime}$ & E104 $53^{\circ} 36.79^{\prime \prime}$ & 2019.07 .25 & nymph & 4 & 0 & h $4(4)$ \\
\hline GZGY1 & $\mathrm{N} 26^{\circ} 35^{\prime} 33.05^{\prime \prime}$ & E106 $43^{\prime} 7.60^{\prime \prime}$ & 2019.10 .08 & adult & 1 & 0 & h 24 \\
\hline GZRH1 & $\mathrm{N} 27^{\circ} 50^{\prime} 48.13^{\prime \prime}$ & E106 $20^{\prime} 51.17^{\prime \prime}$ & 2019.10.02 & adult & 2 & 0 & h 24 \\
\hline GZZY1 & $\mathrm{N} 28^{\circ} 35^{\prime} 24.74^{\prime \prime}$ & E107 $35^{\circ} 55.73^{\prime \prime}$ & 2019.08.09 & adult & 1 & 0 & h 24 \\
\hline GXTM2 & $\mathrm{N} 24^{\circ} 11^{\prime} 31.18^{\prime \prime}$ & E109 $58^{\prime} 44.90^{\prime \prime}$ & & & 1 & 0 & h 4 \\
\hline
\end{tabular}




\begin{tabular}{|c|c|c|c|c|c|c|c|}
\hline population & Lat. & Long. & Sampling time & phase & Sample size & $\mathrm{S}$ & Hap \\
\hline GXLG2 & $\mathrm{N} 25^{\circ} 15^{\prime} 3.64^{\prime \prime}$ & $\mathrm{E} 110^{\circ} 11^{\prime} 20.83^{\prime \prime}$ & & & 1 & 0 & $\mathrm{~h} 4$ \\
\hline GXPM2 & $\mathrm{N} 22^{\circ} 56^{\prime} 40.47^{\prime \prime}$ & E105ㄷำ $35.62^{\prime \prime}$ & 2019.04 .20 & adult & 7 & 2 & h $4(5)$, h $17(1)$, h $18(1)$ \\
\hline GXSL2 & $\mathrm{N} 23^{\circ} 36^{\prime} 42.50^{\prime \prime}$ & E108 $33^{\prime} 25.47^{\prime \prime}$ & 2019.04 .18 & adult & 3 & 3 & h $4(1)$, h $19(1)$, h $20(1)$ \\
\hline GXJX2 & $\mathrm{N} 23^{\circ} 04^{\prime} 14.23^{\prime \prime}$ & $\mathrm{E} 106^{\circ} 27^{\prime} 20.61^{\prime \prime}$ & 2019.04 .19 & adult & 4 & 0 & h $4(4)$ \\
\hline ZJJD2 & $\mathrm{N} 29^{\circ} 28^{\prime} 38.51^{\prime \prime}$ & $\mathrm{E} 119^{\circ} 16^{\prime} 33.40^{\prime \prime}$ & & & 1 & 0 & h 4 \\
\hline ZJTT1 & N3008'9.03”' & E11901'14.75" & 2018.09 & adult & 11 & 1 & h $1(9)$, h $13(2)$ \\
\hline ZJTT2 & N3008'9.03"' & $\mathrm{E} 119^{\circ} 01^{\prime} 14.75^{\prime \prime}$ & 2018.09 & nymph & 7 & 2 & h $4(5)$, h14 (1), h 21 (1) \\
\hline ZJFY1 & $\mathrm{N} 27^{\circ} 53^{\prime} 28.88^{\prime \prime}$ & E119¹0'15.09" & 2019.10 .02 & adult & 1 & 0 & h 24 \\
\hline ZJBMS1 & $\mathrm{N} 28^{\circ} 38^{\prime} 38.96^{\prime \prime}$ & E11909' 0.31" & & & 2 & 0 & h 24 \\
\hline ZJTM1 & $\mathrm{N} 30^{\circ} 21^{\prime} 0.63^{\prime \prime}$ & $\mathrm{E} 119^{\circ} 25^{\prime} 28.82^{\prime \prime}$ & 2019.08.16 & nymph & 5 & 3 & h $1(3)$, h $7(2)$ \\
\hline ZJTM2 & $\mathrm{N} 30^{\circ} 21^{\prime} 0.63^{\prime \prime}$ & $\mathrm{E} 119^{\circ} 25^{\prime} 28.82^{\prime \prime}$ & & & 4 & 0 & h $4(4)$ \\
\hline ZJTM3 & $\mathrm{N} 30^{\circ} 21^{\prime} 0.63^{\prime \prime}$ & $\mathrm{E} 119^{\circ} 25^{\prime} 28.82^{\prime \prime}$ & 2019.09.01 & nymph & 1 & 0 & h 2 \\
\hline ZJBSZ1 & $\mathrm{N} 27^{\circ} 45^{\prime} 16.60^{\prime \prime}$ & $\mathrm{E} 119^{\circ} 12^{\prime} 21.25^{\prime \prime}$ & 2019.10 .02 & adult & 25 & 0 & h 24 \\
\hline ZJBSZ2 & $\mathrm{N} 27^{\circ} 45^{\prime} 16.60^{\prime \prime}$ & $\mathrm{E} 119^{\circ} 12^{\prime} 21.25^{\prime \prime}$ & & & 1 & 0 & h 4 \\
\hline ZJQY2 & $\mathrm{N} 27^{\circ} 37^{\prime} 20.59^{\prime \prime}$ & $\mathrm{E} 119^{\circ} 03^{\prime} 28.56^{\prime \prime}$ & & & 1 & 0 & h 4 \\
\hline ZJGT2 & $\mathrm{N} 29^{\circ} 15^{\prime} 29.68^{\prime \prime}$ & $\mathrm{E} 118^{\circ} 08^{\prime} 59.26^{\prime \prime}$ & 2018.10 .03 & nymph & 4 & 1 & h $4(3)$, h $15(1)$ \\
\hline ZJWYL1 & $\mathrm{N} 27^{\circ} 42^{\prime} 50.78^{\prime \prime}$ & E119 $39^{\prime} 29.97^{\prime \prime}$ & 2019.10 .03 & adult & 1 & 0 & h 29 \\
\hline ZJWYL2 & $\mathrm{N} 27^{\circ} 42^{\prime} 50.78^{\prime \prime}$ & $\mathrm{E} 119^{\circ} 39^{\prime} 29.97^{\prime \prime}$ & 2019.10 .03 & nymph & 3 & 0 & h 4 \\
\hline ZJDP1 & $\mathrm{N} 30^{\circ} 0{ }^{\prime} 7.75^{\prime \prime}$ & $\mathrm{E} 120^{\circ} 04^{\prime} 8.21^{\prime \prime}$ & 2019.10 .04 & adult & 32 & 7 & h $1(1)$, h $24(20)$, h $30(8)$, h \\
\hline ZJDP2 & $\mathrm{N} 30^{\circ} 0 ’ 7.75^{\prime \prime}$ & $\mathrm{E} 120^{\circ} 04^{\prime} 8.21^{\prime \prime}$ & 2019.10 .04 & nymph & 9 & 2 & h $4(8)$, h $15(1)$ \\
\hline ZJSX1 & $\mathrm{N} 30^{\circ} 01^{\prime} 57.90^{\prime \prime}$ & $\mathrm{E} 120^{\circ} 34^{\prime} 29.75^{\prime \prime}$ & 2019.10 .01 & adult & 1 & 0 & h 1 \\
\hline ZJSX3 & N3001'57.90"' & $\mathrm{E} 120^{\circ} 34^{\prime} 29.75^{\prime \prime}$ & 2019.10.01 & adult & 17 & 0 & h 2 \\
\hline ZJJL2 & N30 $35^{\prime} 49.36^{\prime \prime}$ & $\mathrm{E} 121^{\circ} 05^{\prime} 46.26^{\prime \prime}$ & & & 9 & 1 & h $4(8)$, h 12 \\
\hline SHCJ3 & $\mathrm{N} 30^{\circ} 47^{\prime} 54.27^{\prime \prime}$ & $\mathrm{E} 121^{\circ} 24^{\prime} 6.62^{\prime \prime}$ & & & 1 & 0 & h 2 \\
\hline SHCM1 & $\mathrm{N} 31^{\circ} 37^{\prime} 28.83^{\prime \prime}$ & $\mathrm{E} 121^{\circ} 23^{\prime} 33.41^{\prime \prime}$ & & & 1 & 0 & h 1 \\
\hline SHJS3 & $\mathrm{N} 30^{\circ} 43^{\prime} 2.21^{\prime \prime}$ & E121ํ19'33.99”' & & & 1 & 0 & h 2 \\
\hline SHMH3 & $\mathrm{N} 31^{\circ} 01^{\prime} 58.20^{\prime \prime}$ & $\mathrm{E} 121^{\circ} 26^{\prime} 59.25^{\prime \prime}$ & 2019.09 & adult & 3 & 0 & h 2 \\
\hline SHBS1 & $\mathrm{N} 31^{\circ} 24^{\prime} 25.97^{\prime \prime}$ & $\mathrm{E} 121^{\circ} 29^{\prime} 5.70^{\prime \prime}$ & 2019.07 .25 & adult & 14 & 1 & h $1(5)$, h $7(6)$, h $22(2)$, h 2 \\
\hline SHBS3 & $\mathrm{N} 31^{\circ} 24^{\prime} 25.97^{\prime \prime}$ & $\mathrm{E} 121^{\circ} 29^{\prime} 5.70^{\prime \prime}$ & 2019.07 .25 & adult & 10 & 1 & h $2(9)$, h $26(1)$ \\
\hline \multicolumn{8}{|l|}{ SWC } \\
\hline YNKM1 & $\mathrm{N} 24^{\circ} 52^{\prime} 58.97^{\prime \prime}$ & E10249'53.66" & 2019.08.18 & nymph & 28 & 0 & h 24 \\
\hline YNBS1 & $\mathrm{N} 25^{\circ} 07^{\prime} 16.90^{\prime \prime}$ & E99 $09^{\prime} 5.34^{\prime \prime}$ & & & 1 & 0 & h 24 \\
\hline YNMK1 & $\mathrm{N} 25^{\circ} 26^{\prime} 40.25^{\prime \prime}$ & $\mathrm{E} 98^{\circ} 51^{\prime} 38.72^{\prime \prime}$ & 2019.08.20 & nymph & 3 & 0 & h 27 \\
\hline YNHK2 & $\mathrm{N} 22^{\circ} 30^{\prime} 26.16^{\prime \prime}$ & 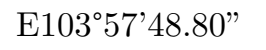 & 2019.08.19 & nymph & 1 & 0 & h 4 \\
\hline \multicolumn{8}{|l|}{$\mathrm{SC}$} \\
\hline SZ1 & $\mathrm{N} 22^{\circ} 32^{\prime} 43.85^{\prime \prime}$ & $\mathrm{E} 114^{\circ} 03^{\prime} 10.40^{\prime \prime}$ & & & 2 & 0 & h 9 \\
\hline FJWY2 & $\mathrm{N} 27^{\circ} 52^{\prime} 27.58^{\prime \prime}$ & E117º51’22.43”' & & & 2 & 0 & h 4 \\
\hline GDHY2 & $\mathrm{N} 22^{\circ} 47^{\prime} 28.70^{\prime \prime}$ & $\mathrm{E} 114^{\circ} 27^{\prime} 7.57^{\prime \prime}$ & & & 1 & 0 & h 4 \\
\hline HNTGL2 & $\mathrm{N} 19^{\circ} 39^{\prime} 15.29^{\prime \prime}$ & $\mathrm{E} 111^{\circ} 01^{\prime} 15.55^{\prime \prime}$ & & & 2 & 0 & h 4 \\
\hline HNJFL2 & $\mathrm{N} 18^{\circ} 42^{\prime} 57.91^{\prime \prime}$ & E108 $52^{\prime} 18.65^{\prime \prime}$ & 2019.03 & nymph & 5 & 1 & h $4(1)$, h $16(4)$ \\
\hline HNWZ2 & N18 $46^{\prime} 37.03^{\prime \prime}$ & $\mathrm{E} 109^{\circ} 30^{\prime} 46.33^{\prime \prime}$ & 2019.03 & adult & 1 & 0 & h 4 \\
\hline HNXA2 & N19 $40^{\prime} 50.21^{\prime \prime}$ & $\mathrm{E} 110^{\circ} 21^{\prime} 52.01^{\prime \prime}$ & 2019.03 & adult & 1 & 0 & h 16 \\
\hline HNCJ2 & N19 $17^{\prime} 59.51^{\prime \prime}$ & $\mathrm{E} 109^{\circ} 03^{\prime} 5.28^{\prime \prime}$ & 2019.03 & adult & 1 & 0 & h 16 \\
\hline TWNT2 & $\mathrm{N} 23^{\circ} 55^{\prime} 10.63^{\prime \prime}$ & $\mathrm{E} 120^{\circ} 40^{\prime} 12.03^{\prime \prime}$ & & & 1 & 0 & h 6 \\
\hline TWWL2 & $\mathrm{N} 24^{\circ} 52^{\prime} 21.08^{\prime \prime}$ & $\mathrm{E} 121^{\circ} 32^{\prime} 51.11^{\prime \prime}$ & & & 1 & 0 & h 6 \\
\hline \multicolumn{8}{|l|}{ KJ } \\
\hline KR2 & N35 $52^{\prime} 17.17^{\prime \prime}$ & $\mathrm{E} 128^{\circ} 36^{\prime} 5.20^{\prime \prime}$ & & & 1 & 0 & h 3 \\
\hline JPSH2 & 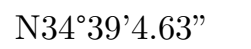 & $\mathrm{E} 135^{\circ} 10^{\prime} 32.81^{\prime \prime}$ & & & 1 & 0 & h 3 \\
\hline JPSH3 & 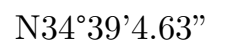 & $\mathrm{E} 135^{\circ} 10^{\prime} 32.81^{\prime \prime}$ & & & 1 & 0 & h 5 \\
\hline JPJG2 & $\mathrm{N} 34^{\circ} 58^{\prime} 37.63^{\prime \prime}$ & $\mathrm{E} 138^{\circ} 22^{\prime} 59.11^{\prime \prime}$ & & & 1 & 0 & h 6 \\
\hline
\end{tabular}




\begin{tabular}{|c|c|c|c|c|c|c|}
\hline population & Lat. & Long. & Sampling time phase & Sample size & $\mathrm{S}$ & Hap \\
\hline JPDB2 & $\mathrm{N} 34^{\circ} 41^{\prime} 37.46^{\prime \prime}$ & E135'30'7.79" & & 1 & 0 & h 6 \\
\hline JPDB3 & $\mathrm{N} 34^{\circ} 41^{\prime} 37.46^{\prime \prime}$ & E135 30'7.79"' & & 1 & 0 & h 5 \\
\hline JPBHD3 & N43'13'13.18" & E14251’48.51” & & 1 & 0 & h 10 \\
\hline JPBK3 & N350’ $44.02^{\prime \prime}$ & E $134^{\circ} 29^{\prime} 1.11^{\prime \prime}$ & & 1 & 0 & h 11 \\
\hline JPQS3 & $\mathrm{N} 40^{\circ} 49^{\prime} 19.46^{\prime \prime}$ & E14044'50.51" & & 1 & 0 & h 10 \\
\hline JPXX3 & N3755'36.72"' & $\mathrm{E} 139^{\circ} 20^{\prime} 22.56^{\prime \prime}$ & & 1 & 0 & h 10 \\
\hline JPSS3 & N33 $50^{\circ} 20.97^{\prime \prime}$ & $\mathrm{E} 132^{\circ} 45^{\prime} 56.07^{\prime \prime}$ & & 1 & 0 & h 5 \\
\hline \multicolumn{7}{|l|}{ VK } \\
\hline VN2 & $\mathrm{N} 21^{\circ} 02^{\prime} 36.57^{\prime \prime}$ & E10551’51.33”' & & 1 & 0 & h 4 \\
\hline KH2 & $\mathrm{N} 12^{\circ} 43^{\prime} 33.90^{\prime \prime}$ & $\mathrm{E} 104^{\circ} 45^{\prime} 56.25^{\prime \prime}$ & & 2 & 0 & h 4 \\
\hline \multicolumn{7}{|l|}{ USA } \\
\hline USAGA3 & N33 $74^{\prime} 83.04^{\prime \prime}$ & W84 $39^{\prime} 11.13^{\prime \prime}$ & & 1 & 0 & h 5 \\
\hline USATN3 & N37 $09^{\circ} 37.14^{\prime \prime}$ & W86 $18^{\prime} 30.94^{\prime \prime}$ & & 1 & 0 & h 5 \\
\hline USAMO1 & N38 $32^{\prime} 53.40^{\prime \prime}$ & $\mathrm{W} 90^{\circ} 21^{\prime} 5.63^{\prime \prime}$ & & 1 & 0 & h 7 \\
\hline USAMO3 & N38 $32^{\prime} 53.40^{\prime \prime}$ & 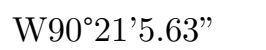 & & 1 & 0 & h 8 \\
\hline USAVA1 & $\mathrm{N} 37^{\circ} 75^{\prime} 88.48^{\prime \prime}$ & W77 $77^{\circ} 93.41^{\prime \prime}$ & & 1 & 0 & h 7 \\
\hline Total & & & & 346 & 32 & \\
\hline
\end{tabular}

Table 3 Sampling details of the genus Velarifictorus .

\begin{tabular}{|c|c|c|c|c|}
\hline & Coordinates & & & \\
\hline Species (population) & Lat. & Long. & GenBank No. & Reference \\
\hline Velarifictorus_dianxiensis & $\mathrm{N} 24^{\circ} 44^{\prime} 58.9^{\prime \prime}$ & $\mathrm{E} 97^{\circ} 33^{\prime} 45.54^{\prime \prime}$ & MH992037 & Chen et al., 2018 \\
\hline Velarifictorus_beybienkoi & N37²5' 58.84"' & $\mathrm{E} 118^{\circ} 40^{\prime} 8.54^{\prime \prime}$ & MH992030 & Chen et al., 2018 \\
\hline Velarifictorus_aspersus & $\mathrm{N} 27^{\circ} 21^{\prime} 16.49^{\prime \prime}$ & $\mathrm{E} 119^{\circ} 55^{\prime} 57.38^{\prime \prime}$ & MH992029 & Chen et al., 2018 \\
\hline Velarifictorus_flavifrons & $\mathrm{N} 21^{\circ} 55^{\prime} 37.21^{\prime \prime}$ & $\mathrm{E} 101^{\circ} 15^{\prime} 22.31^{\prime \prime}$ & MH992033 & Chen et al., 2018 \\
\hline Velarifictorus_ornatus & N253' $19.37^{\prime \prime}$ & $\mathrm{E} 110^{\circ} 25^{\prime} 32.11^{\prime \prime}$ & MH992024 & Chen et al., 2018 \\
\hline $\begin{array}{l}\text { Velarifictorus_agitatus } \\
\text { Velarifictorus_micado }\end{array}$ & $\mathrm{N} 22^{\circ} 09^{\prime} 4.00^{\prime \prime}$ & $\mathrm{E} 100^{\circ} 41^{\prime} 29.04 "$ & in submitting & this study \\
\hline HLJ & $\mathrm{N} 46^{\circ} 02^{\prime} 57.67^{\prime \prime}$ & $\mathrm{E} 125^{\circ} 57^{\prime} 22.18^{\prime \prime}$ & in submitting & this study \\
\hline $\mathrm{LN}$ & $\mathrm{N} 41^{\circ} 40^{\prime} 30.64^{\prime \prime}$ & $\mathrm{E} 123^{\circ} 27^{\prime} 30.98^{\prime \prime}$ & in submitting & this study \\
\hline $\mathrm{JL}$ & $\mathrm{N} 43^{\circ} 50^{\prime} 45.16^{\prime \prime}$ & E1263' $35.93^{\prime \prime}$ & in submitting & this study \\
\hline BJ & N39 $54^{\prime} 11.46^{\prime \prime}$ & $\mathrm{E} 116^{\circ} 24^{\prime} 2.71^{\prime \prime}$ & in submitting & this study \\
\hline HNJY & $\mathrm{N} 35^{\circ} 04^{\prime} 42.16^{\prime \prime}$ & $\mathrm{E} 112^{\circ} 42^{\prime} 26.30^{\prime \prime}$ & in submitting & this study \\
\hline HNPY & $\mathrm{N} 35^{\circ} 51^{\prime} 7.02^{\prime \prime}$ & $\mathrm{E} 115^{\circ} 29^{\prime} 53.63^{\prime \prime}$ & in submitting & this study \\
\hline SXXA & $\mathrm{N} 34^{\circ} 20^{\prime} 33.29^{\prime \prime}$ & E108 $56^{\circ} 7.28^{\prime \prime}$ & in submitting & this study \\
\hline SXNS & $\mathrm{N} 33^{\circ} 18^{\prime} 44.97^{\prime \prime}$ & 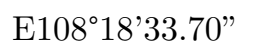 & in submitting & this study \\
\hline SCCD & N30 $39^{\prime} 8.18^{\prime \prime}$ & E10404'20.98' & in submitting & this study \\
\hline SDDY & $\mathrm{N} 37^{\circ} 26^{\prime} 53.41^{\prime \prime}$ & E118 $34^{\prime} 35.12^{\prime \prime}$ & in submitting & this study \\
\hline SDTA & $\mathrm{N} 36^{\circ} 0^{\prime} 3.16^{\prime \prime}$ & $\mathrm{E} 116^{\circ} 43^{\prime} 12.42^{\prime \prime}$ & in submitting & this study \\
\hline HBXY & $\mathrm{N} 32^{\circ} 0 ' 39.61^{\prime \prime}$ & $\mathrm{E} 112^{\circ} 06^{\prime} 57.21^{\prime \prime}$ & in submitting & this study \\
\hline HBWH & $\mathrm{N} 32^{\circ} 0 ' 39.61^{\prime \prime}$ & $\mathrm{E} 112^{\circ} 06^{\prime} 57.21^{\prime \prime}$ & in submitting & this study \\
\hline ANNF & $\mathrm{N} 31^{\circ} 49^{\prime} 20.30^{\prime \prime}$ & E117¹3'17.39" & in submitting & this study \\
\hline JSNJ & $\mathrm{N} 32^{\circ} 03^{\prime} 57.43^{\prime \prime}$ & 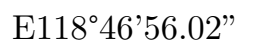 & in submitting & this study \\
\hline JSYZ & N32²3'46.68" & E119²4'27.01" & in submitting & this study \\
\hline JSZJ & N3211'25.78" & $\mathrm{E} 119^{\circ} 25^{\prime} 6.73^{\prime \prime}$ & in submitting & this study \\
\hline GZXY & $\mathrm{N} 25^{\circ} 05^{\prime} 41.85^{\prime \prime}$ & 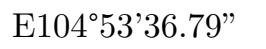 & in submitting & this study \\
\hline GZGY & $\mathrm{N} 26^{\circ} 35^{\prime} 33.05^{\prime \prime}$ & $\mathrm{E} 106^{\circ} 43^{\prime} 7.60^{\prime \prime}$ & in submitting & this study \\
\hline GZRH & $\mathrm{N} 27^{\circ} 50^{\prime} 48.13^{\prime \prime}$ & 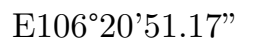 & in submitting & this study \\
\hline
\end{tabular}




\begin{tabular}{|c|c|c|c|c|}
\hline & Coordinates & & & \\
\hline$\overline{\mathrm{GZZY}}$ & N28 $35^{\prime} 24.74^{\prime \prime}$ & $\mathrm{E} 107^{\circ} 35^{\prime} 55.73^{\prime \prime}$ & in submitting & this study \\
\hline GXTM & $\mathrm{N} 24^{\circ} 11^{\prime} 31.18^{\prime \prime}$ & E109 $58^{\circ} 44.90^{\prime \prime}$ & in submitting & this study \\
\hline GXLG & N2515’3.64" & E110¹1'20.83' & in submitting & this study \\
\hline GXPM & $\mathrm{N} 22^{\circ} 56^{\prime} 40.47^{\prime \prime}$ & E105 $59^{\prime} 35.62^{\prime \prime}$ & in submitting & this study \\
\hline GXSL & N233' $42.50^{\prime \prime}$ & E108³3'25.47' & in submitting & this study \\
\hline GXJX & N2304'14.23" & E106 $27^{\circ} 20.61^{\prime \prime}$ & in submitting & this study \\
\hline ZJJD & N29 $28^{\circ} 38.51^{\prime \prime}$ & E119¹6'33.40" & in submitting & this study \\
\hline ZJTT & N3008'9.03"' & E11901'14.75" & in submitting & this study \\
\hline ZJFY & $\mathrm{N} 27^{\circ} 53^{\prime} 28.88^{\prime \prime}$ & E119¹0' 15.09" & in submitting & this study \\
\hline ZJBMS & N28 $38^{\prime} 38.96 "$ & E11909' 0.31" & in submitting & this study \\
\hline ZJTM & N30² $21^{\prime} 0.63^{\prime \prime}$ & $\mathrm{E} 119^{\circ} 25^{\prime} 28.82^{\prime \prime}$ & in submitting & this study \\
\hline ZJBSZ & $\mathrm{N} 27^{\circ} 45^{\prime} 16.60^{\prime \prime}$ & $\mathrm{E} 119^{\circ} 12^{\prime} 21.25^{\prime \prime}$ & in submitting & this study \\
\hline ZJQY & N27³7'20.59”' & E11903'28.56" & in submitting & this study \\
\hline ZJGT & N29¹5'29.68" & E118 08'59.26" & in submitting & this study \\
\hline ZJWYL & $\mathrm{N} 27^{\circ} 42^{\prime} 50.78^{\prime \prime}$ & E119³9'29.97" & in submitting & this study \\
\hline ZJDP & $\mathrm{N} 30^{\circ} 0^{\prime} 7.75^{\prime \prime}$ & E12004'8.21" & in submitting & this study \\
\hline ZJSX & N3001'57.90" & $\mathrm{E} 120^{\circ} 34^{\prime} 29.75^{\prime \prime}$ & in submitting & this study \\
\hline ZJJL & N30³5'49.36" & $\mathrm{E} 121^{\circ} 05^{\prime} 46.26^{\prime \prime}$ & in submitting & this study \\
\hline SHCJ & N30 $47^{\circ} 54.27^{\prime \prime}$ & E121 ${ }^{\circ} 24^{\prime} 6.62^{\prime \prime}$ & in submitting & this study \\
\hline $\mathrm{SHCM}$ & N31 $37^{\circ} 28.83^{\prime \prime}$ & E121 $23^{\prime} 33.41^{\prime \prime}$ & in submitting & this study \\
\hline SHJS & $\mathrm{N} 30^{\circ} 43^{\prime} 2.21^{\prime \prime}$ & E121 ${ }^{\circ} 19^{\prime} 33.99^{\prime \prime}$ & in submitting & this study \\
\hline $\mathrm{SHMH}$ & N31 $01^{\prime} 58.20^{\prime \prime}$ & $\mathrm{E} 121^{\circ} 26^{\prime} 59.25^{\prime \prime}$ & in submitting & this study \\
\hline SHBS & N31 $24^{\circ} 25.97^{\prime \prime}$ & E121 $29^{\circ} 5.70^{\prime \prime}$ & in submitting & this study \\
\hline YNKM & 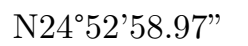 & E102 $49^{\prime} 53.66^{\prime \prime}$ & in submitting & this study \\
\hline YNBS & N2507'16.90" & E99 09'5.34" & in submitting & this study \\
\hline YNMK & $\mathrm{N} 25^{\circ} 26^{\prime} 40.25^{\prime \prime}$ & E98 $51^{\prime} 38.72^{\prime \prime}$ & in submitting & this study \\
\hline YNHK & $\mathrm{N} 22^{\circ} 30^{\prime} 26.16^{\prime \prime}$ & E103 ${ }^{\circ} 57^{\prime} 48.80^{\prime \prime}$ & in submitting & this study \\
\hline $\mathrm{SZ}$ & $\mathrm{N} 22^{\circ} 32^{\prime} 43.85^{\prime \prime}$ & E114 $03^{\prime} 10.40^{\prime \prime}$ & in submitting & this study \\
\hline FJWY & $\mathrm{N} 27^{\circ} 52^{\prime} 27.58^{\prime \prime}$ & $\mathrm{E} 117^{\circ} 51^{\prime} 22.43^{\prime \prime}$ & in submitting & this study \\
\hline GDHY & N22 $47^{\circ} 28.70^{\prime \prime}$ & E114 $24^{\circ} 7.57^{\prime \prime}$ & in submitting & this study \\
\hline HNTGL & N19³9'15.29"' & E111 $01 ' 15.55^{\circ}$ & in submitting & this study \\
\hline HNJFL & N1842'57.91" & E10852'18.65" & in submitting & this study \\
\hline HNWZ & N1846’37.03"' & E109³0'46.33" & in submitting & this study \\
\hline HNXA & N1940'50.21" & E110²1'52.01" & in submitting & this study \\
\hline HNCJ & N19¹7'59.51" & E10903'5.28" & in submitting & this study \\
\hline TWNT & N235'ㄷ․ $10.63^{\prime \prime}$ & $\mathrm{E} 120^{\circ} 40^{\prime} 12.03^{\prime \prime}$ & in submitting & this study \\
\hline TWWL & $\mathrm{N} 24^{\circ} 52^{\prime} 21.08^{\prime \prime}$ & E12132'51.11" & in submitting & this study \\
\hline $\mathrm{KR}$ & N355'ㄱ'17.17" & E128 $36^{\prime} 5.20^{\prime \prime}$ & in submitting & this study \\
\hline JPSH & N343'ㄱ․ $63^{\prime \prime}$ & E135¹0'32.81" & in submitting & this study \\
\hline JPJG & N345'ㄱ․ $37.63^{\prime \prime}$ & E138 $22^{\prime} 59.11^{\prime \prime}$ & in submitting & this study \\
\hline JPDB & $\mathrm{N} 34^{\circ} 41^{\prime} 37.46^{\prime \prime}$ & E135³0'7.79" & in submitting & this study \\
\hline JPBHD & N4313'13.18" & E14251'48.51" & in submitting & this study \\
\hline JPBK & N3507'44.02" & E $134^{\circ} 29^{\prime} 1.11^{\prime \prime}$ & in submitting & this study \\
\hline JPQS & $\mathrm{N} 40^{\circ} 49^{\prime} 19.46^{\prime \prime}$ & E14044'50.51" & in submitting & this study \\
\hline JPXX & N3755’36.72"' & $\mathrm{E} 139^{\circ} 20^{\prime} 22.56^{\prime \prime}$ & in submitting & this study \\
\hline JPSS & N3350'20.97"' & $\mathrm{E} 132^{\circ} 45^{\prime} 56.07^{\prime \prime}$ & in submitting & this study \\
\hline $\mathrm{VN}$ & N21 $02 ' 36.57^{\circ}$ & E10551'51.33" & in submitting & this study \\
\hline $\mathrm{KH}$ & N12 $43^{\prime} 33.90^{\prime \prime}$ & $\mathrm{E} 104^{\circ} 45^{\prime} 56.25^{\prime \prime}$ & in submitting & this study \\
\hline USAGA & N3374'83.04"' & W84º39'11.13" & in submitting & this study \\
\hline USATN & N3709'37.14"' & W86 $18^{\prime} 30.94^{\prime \prime}$ & in submitting & this study \\
\hline
\end{tabular}




\begin{tabular}{|c|c|c|c|c|}
\hline & Coordinates & & & \\
\hline USAMO & N383'고․ & W90² $21^{\prime} 5.63^{\prime \prime}$ & in submitting & this study \\
\hline USAVA & N37 $75^{\prime} 88.48^{\prime \prime}$ & $\mathrm{W} 77^{\circ} 47^{\prime} 93.41^{\prime \prime}$ & in submitting & this study \\
\hline
\end{tabular}

Table 4 Pairwise $\mathrm{F}_{\mathrm{ST}}$ values for the three defined groups of Velarifictorus micado based on COI. ${ }^{* * *} \mathrm{P} ; 0.001$

\begin{tabular}{llll}
\hline & $\mathrm{NE}$ & $\mathrm{SE}$ & $\mathrm{SN}$ \\
\hline $\mathrm{NE}$ & 0.00000 & & \\
$\mathrm{SE}$ & $0.95061^{* * *}$ & 0.00000 & \\
$\mathrm{SN}$ & $0.95084^{* * *}$ & $0.87072^{* * *}$ & 0.00000 \\
\hline
\end{tabular}

Table 5 AMOVA in Velarifictorus micado categorized by different life cycles and corresponding fixation indices based on COI marker. d.f., Degree of freedom; SS, sum of squares; VC, variance components; \%V, percentage of variation; $\mathrm{F}$, multilocus $\mathrm{F}$-statistic; $\mathrm{F}_{\mathrm{CT}}$, Variation among groups; $\mathrm{F}_{\mathrm{SC}}$, Variation among populations within groups; $\mathrm{F}_{\mathrm{ST}}$, Variation within populations.

\begin{tabular}{lllllll}
\hline Source of variation & d.f. & SS & VC & \%V & $\mathbf{F}$ & P \\
\hline Among groups & 2 & 1329.952 & 5.88524 & 93.23 & $\mathrm{~F}_{\mathrm{CT}}=0.93227$ & 0.00000 \\
Among populations within groups & 82 & 92.395 & 0.25222 & 4.00 & $\mathrm{~F}_{\mathrm{SC}}=0.58988$ & 0.00000 \\
Within populations & 261 & 45.768 & 0.17536 & 2.78 & $\mathrm{~F}_{\mathrm{ST}}=0.97222$ & 0.00000 \\
\hline
\end{tabular}

Table 6 AMOVA in Velarifictorus micado categorized by zoogeographic regions and corresponding fixation indices based on COI marker. d.f., Degree of freedom; SS, sum of squares; VC, variance components; \%V, percentage of variation; $\mathrm{F}$, multilocus $\mathrm{F}$-statistic; $\mathrm{F}_{\mathrm{CT}}$, Variation among groups; $\mathrm{F}_{\mathrm{SC}}$, Variation among populations within groups; $\mathrm{F}_{\mathrm{ST}}$, Variation within populations.

\begin{tabular}{lllllll}
\hline Source of variation & d.f. & SS & VC & \%V & F & P \\
\hline Among groups & 7.00 & 424.959 & 1.24315 & 24.94 & $\mathrm{~F}_{\mathrm{CT}}=0.24943$ & 0.00000 \\
Among populations within groups & 74.00 & 970.888 & 3.46700 & 69.56 & $\mathrm{~F}_{\mathrm{SC}}=0.92682$ & 0.00000 \\
Within populations & 264.00 & 72.268 & 0.27374 & 5.49 & $\mathrm{~F}_{\mathrm{ST}}=0.94507$ & 0.00684 \\
\hline
\end{tabular}

Table 7 AMOVA in Velarifictorus micado categorized by different regions and corresponding fixation indices based on CytB marker. d.f., Degree of freedom; SS, sum of squares; VC, variance components; \%V, percentage of variation; $\mathrm{F}$, multilocus $\mathrm{F}$-statistic; $\mathrm{F}_{\mathrm{CT}}$, Variation among groups; $\mathrm{F}_{\mathrm{SC}}$, Variation among populations within groups; $\mathrm{F}_{\mathrm{ST}}$, Variation within populations.

\begin{tabular}{lllllll}
\hline Source of variation & d.f. & SS & VC & \%V & F & P \\
\hline Among groups & 10.00 & 418.250 & 1.87379 & 41.11 & $\mathrm{~F}_{\mathrm{CT}}=0.41111$ & 0.03030 \\
Among populations within groups & 12.00 & 85.679 & 1.37792 & 30.23 & $\mathrm{~F}_{\mathrm{SC}}=0.51336$ & 0.00000 \\
Within populations & 139.00 & 181.565 & 1.30622 & 28.66 & $\mathrm{~F}_{\mathrm{ST}}=0.71342$ & 0.00000 \\
\hline
\end{tabular}

Table 8 AMOVA in Velarifictorus micado based on CytB categorized three clades according COI and corresponding fixation indices based on CytB marker d.f., Degree of freedom; SS, sum of squares; VC, variance components; $\% \mathrm{~V}$, percentage of variation; $\mathrm{F}$, multilocus $\mathrm{F}$-statistic; $\mathrm{F}_{\mathrm{CT}}$, Variation among groups; $\mathrm{F}_{\mathrm{SC}}$, 
Variation among populations within groups; $\mathrm{F}_{\mathrm{ST}}$, Variation within populations.

\begin{tabular}{lllllll}
\hline Source of variation & d.f. & SS & VC & \%V & F & P \\
\hline Among groups & 2.00 & 551.278 & 5.10265 & 84.78 & $\mathrm{~F}_{\mathrm{CT}}=0.84778$ & 0.00000 \\
Among populations within groups & 25.00 & 72.514 & 0.45573 & 7.57 & $\mathrm{~F}_{\mathrm{SC}}=0.49742$ & 0.00000 \\
Within populations & 134.00 & 61.702 & 0.46046 & 7.65 & $\mathrm{~F}_{\mathrm{ST}}=0.92350$ & 0.00293 \\
\hline
\end{tabular}

Table 9 Neutrality tests in each geographic population based on CytB. S, number of segregating sites; Hap, haplotype distribution.

\begin{tabular}{|c|c|c|c|c|c|}
\hline population & Hap & Sample size & S & Tajima' D & $\mathrm{Fu}$ ' Fs \\
\hline HLJ & h $13(9)$, h 14 & 10 & 1 & -1.11173 & -0.33931 \\
\hline HNJY & h $12(11)$, h17, h 32, h 33, h34 & 15 & 4 & $-1.81594^{*}$ & $-3.228^{*}$ \\
\hline GZXY & h $4(7)$, h 27, h 28, h29, h 31 & 11 & 5 & $-1.21975^{*}$ & $-1.68362^{*}$ \\
\hline YNKM & h $4(6)$, h $25(14)$, h 26 , & 21 & 2 & -0.13298 & -0.09012 \\
\hline HBXY & h $1(2)$, h $35(2)$ & 4 & 3 & -0.07339 & 1.77498 \\
\hline HBWH & h $2(1)$ & 1 & & & \\
\hline ANHF & h 1, h 17 & 2 & 17 & & \\
\hline ZJTT & h $1(7)$, h $2(3)$, h 3, h 4 , h 11 & 13 & 6 & -0.75444 & -0.69700 \\
\hline ZJGT & h $2(4)$ & 4 & 0 & & \\
\hline ZJTM & h 1 & 1 & & & \\
\hline ZJSX & h $12(1)$, h $16(1)$, h17(2), h 36(1) & 5 & 4 & -0.41017 & -1.19500 \\
\hline SDDY & h 1, h $12(6)$, h 15, h 18, h 19, h 20, h 21 & 12 & 22 & -0.89013 & 0.37100 \\
\hline SDTA & h $12(7)$, h $17(2)$, h 19, h 22, h 23, h 24 & 13 & 5 & -1.57943 & $-3.489^{*}$ \\
\hline SHMH & h $12(1)$, h $17(2)$ & 3 & 1 & & \\
\hline SHBS & h $1(7)$, h $12(5)$, h $15(5)$, h 16 , h $17(2)$, h 30 & 21 & 21 & $2.23545^{*}$ & $6.159^{*}$ \\
\hline GXPM & h $4(5)$, h $8(2)$ & 7 & 2 & 0.68731 & 1.70200 \\
\hline GXSL & h $4(2)$, h 9 & 3 & 1 & & \\
\hline GXJX & h $4(1)$, h $8(2), h 10(2)$ & 5 & 3 & 1.57274 & 0.46900 \\
\hline HNBS & h 4 & 1 & & & \\
\hline HNJFL & h $4(1)$, h $5(1)$, h $6(2)$ & 4 & 2 & & \\
\hline HNWZ & h 4 & 1 & & & \\
\hline HNXA & h $4(2)$, h $5(1)$ & 3 & 1 & & \\
\hline HNCJ & h $5(1)$, h $7(1)$ & 2 & 2 & & \\
\hline
\end{tabular}

Fig.1 Sampling localities of Velarifictorus micado.

Fig.2 Median-joining haplotype network based on COI construced using DNASP and Popart, circle size represented the number of the haplotype, the different color represented the different populations.

Fig.3 Median-joining haplotype network based on CytB construced using DNASP and Popart, circle size represented the number of the haplotype, the different color represented the different populations.

Fig.4 Time estimation of Velarifictorus micado based on COI constructed using BEAST. The BEAST run was calibrated using the substitution rate of $0.017 \mathrm{subs} / \mathrm{s} / \mathrm{Myr}$, purple bars represent the node age $95 \%$ credible intervals. The numbers of the nodes were the estimated node ages. Green circles and blue circles on nodes indicate posterior probability values over 95 and 90, respectively. 

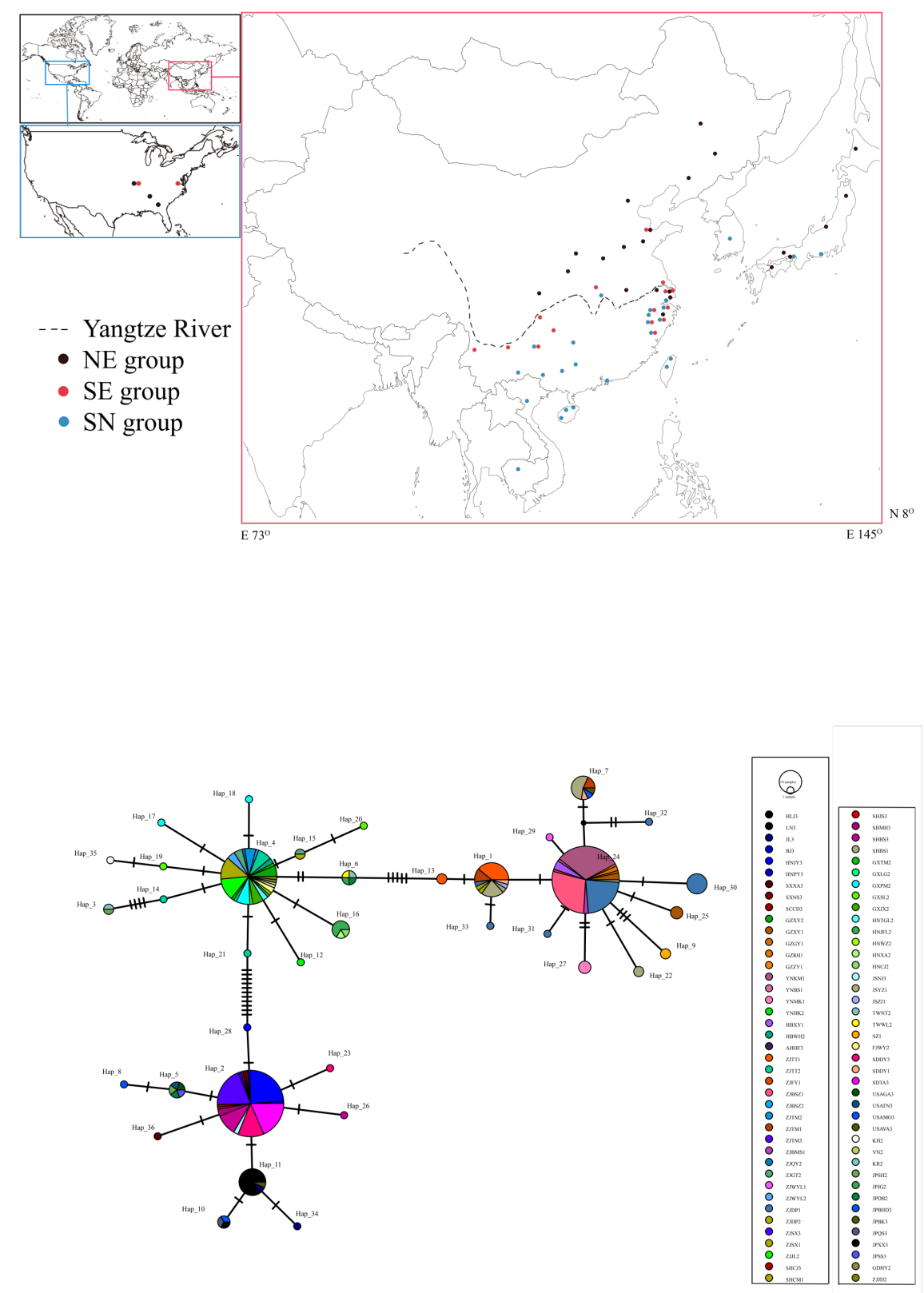

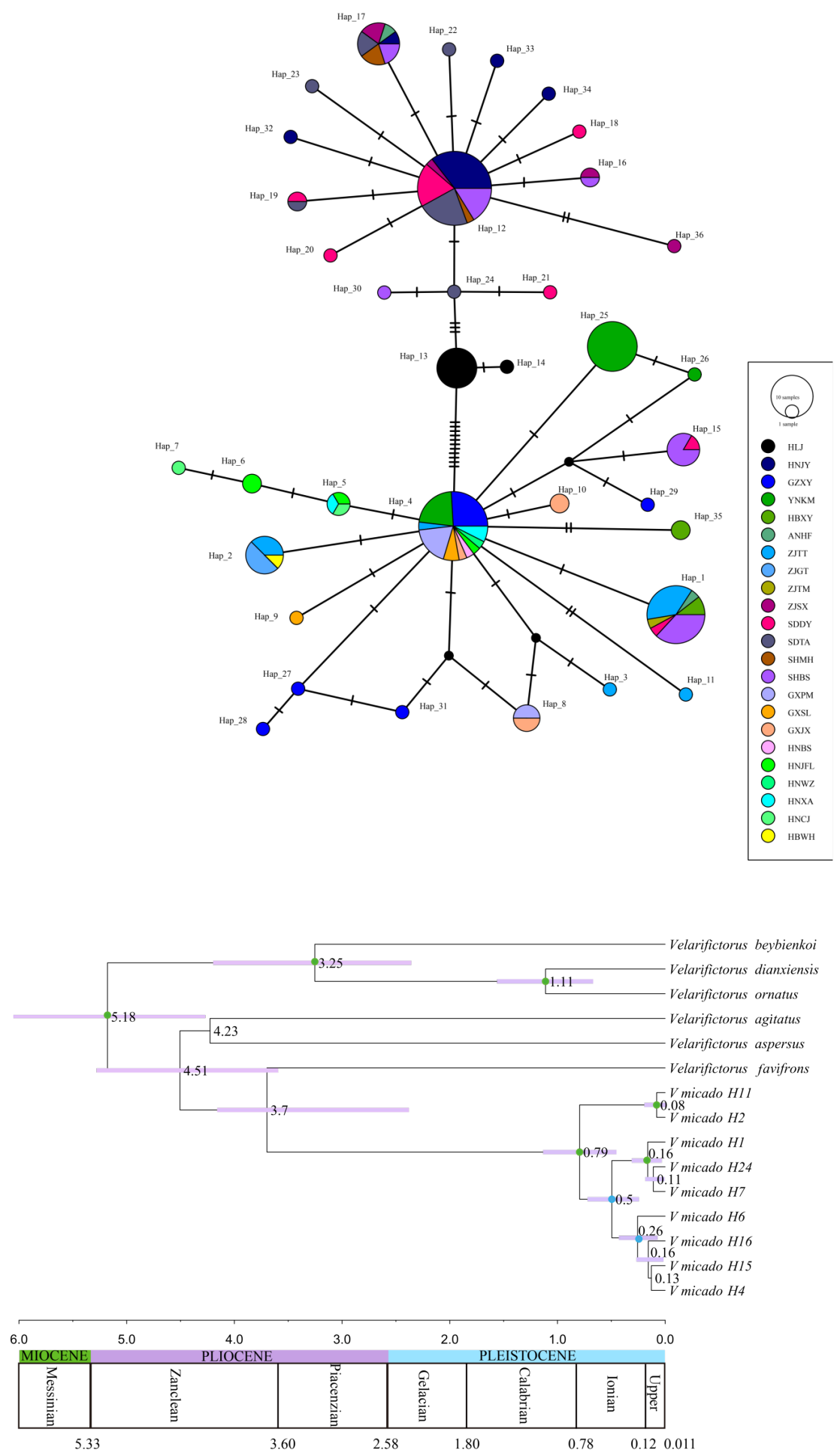